\title{
Severe Thromboembolic Complication Revealing a Nephrotic Syndrome Due to Segmental and Focal Hyalinosis: A Case Report
}

\author{
Sah Dit Baba Coulibaly1, Magara Samaké2,3*, Aboubacar Sidiki Fofana², Seydou Sy, \\ Hamadoun Yattara ${ }^{4,5}$, Nanko Doumbia ${ }^{3,6}$, Katilé Drissa ${ }^{3,7}$, Moctar Coulibaly ${ }^{8}$, Kodio Atabieme ${ }^{4}$, \\ Djénéba Maiga ${ }^{9}$, Aboudou Messoum Dolo9, Nouhoum Coulibaly ${ }^{4}$, Hamat Ibrahim ${ }^{10}$, \\ Saharé Fongoro ${ }^{4,5}$, Konaté Anselme ${ }^{5,11}$ \\ ${ }^{1}$ Nephrology Unit of Somino DOLO Hospital, Mopti, Mali \\ ${ }^{2}$ Nephrology Unit of the Fousseyni DAOU Hospital, Kayes, Mali \\ ${ }^{3}$ National Center for Scientific and Technological Research (CNRST), Bamako, Mali \\ ${ }^{4}$ Faculty of Medicine of Bamako, Bamako, Mali \\ ${ }^{5}$ Department of Nephrology and Haemodialysis, University Teaching Hospital of Point-G, Bamako, Mali \\ ${ }^{6}$ Medicine Department of Mali Hospital, Bamako, Mali \\ ${ }^{7}$ Gastrohepato-Enterology Unit of the Fousseyni DAOU Hospital, Kayes, Mali \\ ${ }^{8}$ Nephrology Unit of the Mali GAVARDO Hospital of Sebenicoro, Bamako, Mali \\ ${ }^{9}$ Nephrology Unit of Sikasso Hospital, Sikasso, Mali \\ ${ }^{10}$ Department of Nephrology-Hemodialysis, National General Reference Hospital, N'Djamena, Chad \\ ${ }^{11}$ Department of Gastro-Hepato-Enterology, Gabriel Touré University Hospital, Bamako, Mali \\ Email: *samake_magara@yahoo.fr
}

How to cite this paper: Coulibaly, S.D.B., Samaké, M., Fofana, A.S., Sy, S., Yattara, H., Doumbia, N., Drissa, K., Coulibaly, M., Atabieme, K., Maiga, D., Dolo, A.M., Coulibaly, N., Ibrahim, H., Fongoro, S. and Anselme, K. (2021) Severe Thromboembolic Complication Revealing a Nephrotic Syndrome Due to Segmental and Focal Hyalinosis: A Case Report. Open Journal of Nephrology, 11, 450457.

https://doi.org/10.4236/ojneph.2021.113037

Received: August 19, 2021

Accepted: September 27, 2021

Published: September 30, 2021

\begin{abstract}
Adult Nephrotic Syndrome (NS) is defined by proteinuria $>3 \mathrm{~g} / 24 \mathrm{~h}$ or 50 $\mathrm{mg} / \mathrm{kg} /$ day, hypoprotidemia $<60 \mathrm{~g} / 24 \mathrm{~h}$, hypoalbuminemia $<30 \mathrm{~g} / \mathrm{L}$. It is a disease with high thromboembolic risk. Peripheral vein thrombosis is common, while its association with pulmonary localizations has been more rarely reported. We report a case of nephrotic syndrome revealed by an association of pulmonary embolism, renal vein and inferior vena cava thrombosis. The diagnosis was confirmed by thoracic angioscan. Renal biopsy revealed Focal Segmental Hyalinosis (FSH). An anti-coagulant treatment and an anti-proteinuric treatment were instituted based on a calcium channel blocker (amlodipine) associated with the conversion enzyme inhibitor (perindopril).
\end{abstract}

\section{Keywords}

Thromboembolic Complication, Nephrotic Syndrome, Segmental and Focal 
Copyright $\odot 2021$ by author(s) and Scientific Research Publishing Inc. This work is licensed under the Creative Commons Attribution International License (CC BY 4.0).

http://creativecommons.org/licenses/by/4.0/
Hyalinosis, Bamako/Mali

\section{Introduction}

Adult Nephrotic Syndrome (NS) is defined by proteinuria $>3 \mathrm{~g} / 24 \mathrm{~h}$ or $50 \mathrm{mg} / \mathrm{kg}$ / day, hypoprotidemia $<60 \mathrm{~g} / 24 \mathrm{~h}$, hypoalbuminemia $<30 \mathrm{~g} / \mathrm{L}$ [1]. It is a disease with high thromboembolic risk. Peripheral vein thrombosis is common, while its association with pulmonary localizations has been more rarely reported. Several factors are incriminated in the genesis of these thromboses. They raise the problem of their diagnosis and especially their management. Adult nephrotic syndrome is a rare entity, and its consequences can be multiple: hypercoagulability, arterial hypertension, undernutrition, and infections [2]. In current practice, it should be systematically investigated in all patients with NS and respiratory discomfort.

We report a case of nephrotic syndrome revealed by an association of pulmonary embolism, renal vein and inferior vena cava thrombosis.

\section{Observation}

This was a 53-year-old female patient, housewife, black race, Malian, admitted to our nephrology department of the G point University Hospital of Bamako, on September 18, 2017, for a symptomatology of progressive installation made of fever, right thoracic pain of side point type, dyspnea stage II of NYHA on a ground of oedematous syndrome (facial puffiness and oedema of the lower limbs) and oligoanuria. She had recent, unbalanced and irregularly monitored hypertension and obesity (Body Mass Index $32 \mathrm{~kg} / \mathrm{m}^{2}$ ). She had no particular family history.

On examination, Blood Pressure was $160 / 100 \mathrm{~mm} \mathrm{Hg}$, axillary temperature was $37.8^{\circ} \mathrm{C}$, heart rate 98 beats per minute. There were bulky edemas of the lower limbs, soft, bilateral, painless, guarding the bucket with presence of facial puffiness and diuresis was estimated at $350 \mathrm{ml}$ per 24 hours.

At the pulmonary level, there was a right pulmonary condensation syndrome. The abdominal examination revealed the presence of a large amount of ascites. The rest of the physical examination was borderline normal.

Biologically, creatinine was $318 \mu \mathrm{mol} / \mathrm{l}$, urea $14.95 \mathrm{mmol} / \mathrm{l}$; the blood count showed a hemoglobin level of $11.3 \mathrm{~g} / \mathrm{dl}$; hyperleukocytosis of $24,400 / \mathrm{mm}^{3}$ with a predominantly neutrophilic polynuclear count of $19,410 / \mathrm{mm}^{3}$ and platelets of $458,000 / \mathrm{mm}^{3}$. The PT was $100 \%$ and the activated partial thromboplastin rate (APTT) was $30 \mathrm{~s} / 30 \mathrm{~s}$. The lipid profile showed a slight hypercholestolemia. Proteinuria at $4.56 \mathrm{~g} / 24 \mathrm{~h}$ without hematuria prompted plasma protein electrophoresis, which revealed hypo-albuminemia at $10.8 \mathrm{~g} / \mathrm{l}$ and hypo-proteinemia at 40 g/l. Hepatic enzymology was normal.

Protein C, protein S and antithrombin III assays were not performed. The immunological workup (anti-nuclear factor and anti-DNA antibodies) was normal.

The infectious workup showed positive hepatitis B serology with a detectable viral load of $17 \mathrm{IU} / \mathrm{ml}, \mathrm{F} 1$ cirrhometer with negative Alpha-Feto-Protein (AFP) 
at $2.09 \mathrm{IU} / \mathrm{ml}$ and normal transaminases.

A frontal chest X-ray showed a right pneumopathy (see Figure 1). An angioscanner was performed, which confirmed a pulmonary embolism associated with a thrombosis of the right renal vein and the inferior vena cava (see Figure 2). Cardiac ultrasound did not show an acute pulmonary heart. The echodoppler of the lower limbs came back normal.

The diagnosis of Impure Nephrotic Syndrome (INS) with thromboembolic (pulmonary embolism, renal vein and inferior vena cava thrombosis) and infectious (lung disease) complications was made.

Treatment consisted of antibiotic therapy with Ceftazidime ( $1 \mathrm{~g}$ every 12 hours for 10 days) and curative anticoagulant treatment with calciparin (250 IU/k every 12 hours). Every 8 hours) and acenocoumarol (1 tablet of $4 \mathrm{mg}$ per day) were instituted followed by a maintenance treatment based on acenocoumarol alone for six (06) months. For nephrotic syndrome, a salt-free diet, fresh plasma infusion (5 units) and treatment with Perindopril, an ACE inhibitor, were initiated.



Figure 1. Chest X-ray performed at the patient's admission: Pulmonary condensation syndrome involving the right lung (right lung disease).



Figure 2. Angioscanner performed on admission of the patient: lobar and segmental pulmonary embolism of the right lower lobe and distal left lower lobe. 
After 4 days of treatment, diuresis resumed with marked regression of the edematous syndrome and on the 10th day of his hospitalization, renal function normalized and his discharge was decided. In view of the risk of promoting HBV viral replication under immunosuppressive treatment, we opted for an antiproteinuric treatment with IEC.

We performed a renal biopsy 6 months later. It concluded to a Segmental and Focal Hyalinosis (SFH) of a glomerulus and the absence of argument in favour of an Extra Membranous Glomerulonephritis (EMG). Immunofluorescence could not be performed.

There was a significant reduction in proteinuria after six months of ACE inhibitor treatment and the last proteinuria control was $0.2 \mathrm{~g} / 24 \mathrm{~h}$; blood pressure remained stable on amlodipine-perindopril combination at $10 \mathrm{mg}$ each.

The patient was still not under antiviral treatment against hepatitis B according to the recommendations of her hepatologist (detectable viral load at $33 \mathrm{IU} / \mathrm{ml}$, cirrhometer at F1 with negative Alpha-Feto-Protein (AFP) at $3.04 \mathrm{IU} / \mathrm{ml}$ and normal transaminases). At one year follow-up on amlodipine-perindopril $10 \mathrm{mg}$, proteinuria was absent. Blood pressure remained normal at the one-year follow-up after negativation of proteinuria and discontinuation of amlodipine and perindopril despite resumption of the normo-saline diet. In terms of hepatitis, the patient did not receive antivirals because of the low viral load and stable liver enzymes. The body mass index remained stable between 31 and $33 \mathrm{~kg} / \mathrm{m}^{2}$. Informed consent was obtained from the patient for case sharing after explaining the purpose of this work.

\section{Discussion}

Nephrotic syndrome and risk factor for thrombosis, among the recognized and classic risk factors for Venous Thromboembolic Disease (VTE), coagulation disorders are reported [3]. Nephrotic syndrome is associated with a state of hypercoagulability by several mechanisms: platelet activation by increased thromboxane A2 activity, increased von Willebrandt factor, increased red blood cell aggregation, glomerular leakage and hyperconsumption of antithrombin III, decreased protein $S$ activity, increased hepatic synthesis of fibrinogen and procoagulant factors V and VII, increased lipoproteins preventing fibrinolysis [4]. The association between NS and VTE is frequent and sometimes underestimated in view of the array of non-specific symptoms accompanying VTE. In a cohort of 512 patients presenting with NS, a routine angioscanner scan found VTE in 180 patients, i.e. a prevalence of $35 \%$. Of these, $83 \%$ (128 patients) were asymptomatic [5]. Thromboembolic events occur most often during a relapse in the first year of the nephrotic syndrome, but they can also occur after a prolonged course [6]. In our patient, the thromboembolic event occurred during the first attack of the nephrotic syndrome. The histological entity found at the renal biopsy of this patient was focal segmental hyalinosis. Contrary to some authors, the incidence of renal vein thrombosis is particularly high, especially in patients with Extra- 
membranous Glomerulonephritis (EMG) or Membranoproliferative Glomerulonephritis (MPGN) [7] [8] [9] [10]. The independent risk factor for VTE was a decreased blood albumin level. This risk was increased by a factor of 2.13 (95\% CI $(1.32$ - 3.46); $\mathrm{p}=0.002)$ with each $1 \mathrm{~g} / \mathrm{dL}$ reduction in albumin [7]. The etiological workup found a hepatitis B viral infection, which usually manifests as GEM and rarely as HSF [11]. Investigation of other causes, haemopathy or malignancy, was negative. In a retrospective study of a cohort of 1958 patients with NS, cancer was found in $5.2 \%$ of patients (lung, skin, hematological disease), i.e. a 2.5 -fold increase in risk at 1 year (95\% CI (1.4 - 3.84)) and a 3.5-fold increase at 2 years ( $95 \%$ CI $(1.37-5.35)$ ) compared to the general population [12]. Similarly, there is a strong association between thrombosis and active cancer, particularly in cases of atypical thrombosis sites (intra-abdominal thrombosis including renal vein thrombosis, upper limb thrombosis, and bilateral lower limb thrombosis) [13]. Thus, in the absence of a consensus, Pani et al. propose a 3-step workup for patients with SN, including clinical examination, biological workup, dedicated imaging (chest X-ray and abdominal ultrasound) and more invasive exploration if necessary [14]. The moderate obesity found in the patient was not considered as responsible for this glomerulopathy because of the disappearance of proteinuria and the normalization of blood pressure despite the stability of the body weight. The usual renal histological appearance described during obesity is Segmental and Focal Glomerulosclerosis (SFGS) associated with Glomerulomegaly (GM) [15] [16] [17] [18].

In the presence of VTE, anticoagulant therapy is indicated as long as the SN persists [19]. Although there is no consensus on the choice of the appropriate molecule, the risks of underdosing due to glomerular leakage of antithrombin III and decreased protein $S$ activity must be taken into account. Warfarin has been used for the longest time, but in the case of hypoalbuminemia, the therapeutic range is narrow. Similarly, low molecular weight heparins in NS require dose adjustment in case of renal failure [19].

The advent of the new direct oral anticoagulants (DOA) could be an interesting element (oral route, no need for biological monitoring). Chaudesaygues et al. introduced rivaroxaban in 3 of their patients who presented with VTE associated with NS with good progression [20]. However, no study has evaluated their indication in the context of NS and they are contraindicated in case of creatinine clearance below $30 \mathrm{~mL} / \mathrm{min}$. Their use is not currently recommended as first-line therapy. There is also no consensus on the duration of treatment. In a review of the literature from 1980 to 2012, Pincus and Hynicka [19] propose curative anti-coagulant therapy for a period of 6 months after diagnosis, a period considered to be the most at risk for VTE [11]. Prophylaxis in case of GEM could be started as soon as the albumin level is below $25 \mathrm{~g} / \mathrm{L}$ [19]. In France, the Haute Autorité de santé recommends primary prophylaxis in the presence of VTE risk factors, including albumin levels $<20 \mathrm{~g} / \mathrm{L}$ or $<25 \mathrm{~g} / \mathrm{L}$ in GEM [21].

The association of pulmonary embolism, renal vein and inferior vena cava 
Table 1. Renal manifestations in hepatitis B.

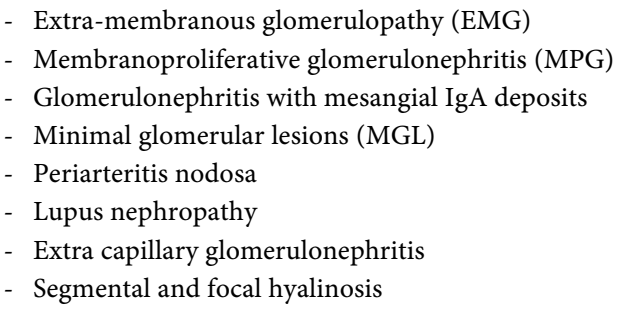

thrombosis is rare, and this is a first case in our department. The histological lesion frequently found in hepatitis B, Extramembranous Glomerulonephritis (EMG), was not found on PBR in the absence of immunofluorescence examination. However, a Segmental and Focal Hyalinosis (SFH) was found on one glomerulus.

Extramembranous Glomerulonephritis (EMG) is the most frequent histological entity among the glomerular disorders described in the context of HBV infection [22] (see Table 1). Hepatitis B-related GEM occurs most frequently in children in endemic areas. In Taiwan, where $17 \%$ of the population is HBsAgpositive, $96 \%$ of children with GEM are HBsAg-positive [23]. HBe antigen appears to be the main culprit in glomerular immune deposition. In the majority of cases, the disease is discovered at the time of the appearance of edema, which reveals a nephrotic syndrome. Treatment with corticosteroids is contraindicated because of the risk of increased viral replication, but antiviral treatment may be beneficial for renal damage [24].

\section{Conclusion}

In the presence of any pulmonary embolism or deep vein thrombosis of idiopathic appearance, a nephrotic syndrome must be systematically sought. The two modes of diagnosis are proteinuria found on $\mathrm{BU}$ and hypoprotidemia on standard biology. Renal abnormalities are frequently observed in patients infected with the hepatitis B virus, but the link with the virus has not been established. Thrombosis is favored by the leakage of coagulation factors (notably antithrombin III) generated by the nephrotic syndrome.

\section{Conflicts of Interest}

No conflict of interest.

\section{References}

[1] Fraisse, C., Nouvier, M., Lainez, S., Nesme, P., Ernesto, S. and Devouassoux, G. (2017) Pulmonary Embolism as a Presentation of Nephrotic Syndrome. Revue des Maladies Respiratoires, 34, 765-769. https://doi.org/10.1016/j.rmr.2016.12.002

[2] Crew, R.J., Radhakrishnan, J. and Appel, G. (2004) Complications of the Nephrotic Syndrome and Their Treatment. Clinical Nephrology, 62, 245-259. https://doi.org/10.5414/CNP62245

[3] Heit, J.A., Michael O’Fallon, W. and Petterson, T.M. (2002) Relative Impact of Risk 
Factors for Deep Vein Thrombosis and Pulmonary Embolism: A Population-Based Study. Archives of Internal Medicine, 162, 1245-1248. https://doi.org/10.1001/archinte.162.11.1245

[4] Zwaginga, J.J., Koomans, H.A., Sixma, J.J. and Rabelink, T.J. (1994) Thrombus Formation and Platelet-Vessel Wall Interaction in the Nephrotic Syndrome under Flow Conditions. Journal of Clinical Investigation, 93, 204-211. https://doi.org/10.1172/JCI116947

[5] Zhang, L.J., Zhang, Z., Li, S.J., Meinel, F.G., Nance, J.W., Sheng Zhou, C., et al. (2014) Pulmonary Embolism and Renal Vein Thrombosis in Patients with Nephrotic Syndrome: Prospective Evaluation of Prevalence and Risk Factors with CT. Radiology, 273, 897-906. https://doi.org/10.1148/radiol.14140121

[6] Gargah, T., Abidi, K., Nourchène, K., Zarrouk, C. and Lakhoua, M.R. (2011) Complications throm-boemboliques du syndrome néphrotique. Tunisie Medicale, 90, 161-165.

[7] Lionaki, S., Derebail, V.K., Hogan, S.L., Barbour, S., Lee, T., Hladunewich, M., et al. (2012) Venous Thromboembolism in Patients with Membranous Nephropathy. Clinical Journal of the American Society of Nephrology, 7, 43-51. https://doi.org/10.2215/CJN.04250511

[8] Bellomo, R. and Atkins, R.C. (1993) Membranous Nephropathy and Thromboembolism: Is Prophylactic Anticoagulation Waranted? Nephron, 63, 249-254. https://doi.org/10.1159/000187205

[9] Bernard, D.B. (1988) Extrarenal Complications of the Nephrotic Syndrome. Kidney International, 33, 1184-1202. https://doi.org/10.1038/ki.1988.129

[10] Llach, F., Papper, S. and Massry, S.G. (1980) The Clinical Spectrum of Renal Vein Thrombosis: Acute and Chronic. American Journal of Medicine, 69, 819-827. https://doi.org/10.1016/S0002-9343(80)80006-4

[11] Francois, H., Mussini, C., Ferlicot, S., Nnang, E., Beaudreuil, S., Ronco, P. and Antoine, D. (2018) HÉPATITES VIRALES ET REIN. Traité de néphrologie, Lavoisier, Paris, chapitre 52, 386.

[12] Birkeland, S.A. and Storm, H.H. (2003) Glomerulonephritis and Malignancy: A Population-Based Analysis. Kidney International, 63, 716-721. https://doi.org/10.1046/j.1523-1755.2003.00771.x

[13] Tafur, A.J., Kalsi, H., Wysokinski, W.E., Bane, R.D.M., Ashrani, A.A., Marks, R., et al. (2011) The Association of Active Cancer with Venous Thromboembolism Location: A Population Based Study. Mayo Clinic Proceedings, 86, 25-30. https://doi.org/10.4065/mcp.2010.0339

[14] Pani, A., Porta, C., Cosmai, L., Melis, P., Floris, M., Piras, D., et al. (2015) Glomerular Diseases and Cancer: Evaluation of under Lying Malignancy. Journal of Nephrology, 10, 143-152. https://doi.org/10.1007/s40620-015-0234-9

[15] Kasiske, B.L. and Crosson, J.T. (1986) Renal Disease in Patients with Massive Obesity. Archives of Internal Medicine, 146, 1105-1109. https://doi.org/10.1001/archinte.1986.00360180095016

[16] Bailey, R.R., Lynn, K.L., Burry, A.F. and Drennan, C. (1989) Proteinuria, Glomerulomegaly and Focal Segmental Glomerulosclerosis in a Grossly Obese Man with Obstructive Sleep Apnea Syndrome. Australian and New Zealand Journal of Medicine, 19, 473-474. https://doi.org/10.1111/j.1445-5994.1989.tb00310.x

[17] Verani, R.R. (1992) Obesity Associated Focal Segmental Glomerulosclerosis: Pathological Features of the Lesion and Relationship with Cardiomegaly and Hyperlipidemia. American Journal of Kidney Diseases, 20, 629-634.

https://doi.org/10.1016/S0272-6386(12)70230-5 
[18] Kambham, N., Markowitz, G.S., Valeri, A.M., Lin, J. and D’Agati, V.D. (2001) Obesity-Related Glomerulopathy: An Emerging Epidemic. Kidney International, 59, 1498-1509. https://doi.org/10.1046/j.1523-1755.2001.0590041498.x

[19] Pincus, K.J. and Hynicka, L.M. (2013) Prophylaxis of Thromboembolic Events in Patients with Nephrotic Syndrome. Annals of Pharmacotherapy, 47, 725-734. https://doi.org/10.1345/aph.1R530

[20] Chaudesaygues, E., Grasse, M., Marchand, L., Villar, E. and Aupetit, J.F. (2014) Embolie pulmonaire révélant un syndrome néphrotique: À propos de quatre cas. Annales de Cardiologie et d' Angéiologie, 63, 385-388. https://doi.org/10.1016/j.ancard.2014.08.010

[21] Protocole National de Diagnostic et de Soins (PNDS) (2014) Syndrome néphrotique idiopathique de l'adulte.

https://www.has-sante.fr/upload/docs/application/pdf/2014-12/pnds - syndrome nephrotique idiopathique de ladulte.pdf

[22] Bhimma, R. and Coovadia, H.M. (2004) Hepatitis B Virus-Associated Nephropathy. American Journal of Nephrology, 24, 198-211. https://doi.org/10.1159/000077065

[23] Hsu, H.-C., Wu, C.-Y., Lin, C.-Y., Lin, G.-J., Chen, C.-H. and Huang, F.-Y. (1989) Membranous Nephropathy in 52 Hepatitis B Surface Antigen (HBsAg) Carrier Children in Taiwan. Kidney International, 36, 1103-1107. https://doi.org/10.1038/ki.1989.307

[24] Tang, S. and Lai, K.N. (2006) Hepatitis B-Related Membranous Nephropathy Should Be Treated with a Specific Anti-Viral Agent. Kidney International, 70, 818. https://doi.org/10.1038/sj.ki.5001586 